\title{
建設副産物の中間処理に伴う二酸化炭素排出量に関する研究 QUANTITY OF CARBON DIOXIDE EMISSION BY THE INTERMEDIÀTE PROCESSING OF THE CONSTRUCTION WASTE
}

\author{
福田俊之*，菊池雅史**，小山明男***，山口善弘**** \\ Toshiyuki FUKUDA, Masafumi KIKUCHI, Akio KOYAMA \\ and Yoshihiro YAMAGUCHI
}

\begin{abstract}
The quantity of carbon dioxide emission discharged from the intermediate processing of the construction waste is analyzed. At the first part, this study was carried out the questionnaire survey toward the intermediate processing plants of the whole country. The yearly quantity of carbon dioxide emission by the intermediate processing of the construction waste was calculated from this result. At the second part, result of the questionnaire survey was tidied in terms of processing methods and items to calculate the carbon dioxide emission per weight. By using these the calculation of the quantity of carbon dioxide emission can be simplified. And these estimated values can contribute to the reduction of the environmental impact as the guide to select the method of the intermediate processing of the construction waste.
\end{abstract}

Keywords : sustainable development, life cycle assessment, carbon dioxide, construction waste, intermediate processing 持続的発展，ライフサイクルアセスメント，二酸化炭素，建設副産物，中間処理

\section{1. はじめに}

近年、『持続的発展可能な経済社会の構築』が、21世紀における国 際的な指標として位㯰付けられ、その具体的な施策が相次いで法制化、 国際的な規格化が推進されている。

その代表的な法律として、「循環型社会形成推進基本法」、「建設工 事に係る資材の再資源化等に関する法律」「国等による環境物品等の 調详の推進等に関する法律」がある。また、製品やそのサービスを前 段階でもたらす環境側面の評価方法等については、ISO14000s がすで に発効し、運用されている。

これら法律や国際規格等では、循環型社会の構築の必須条件として、 製品のライフサイクルの段階で発生する廃棄物・副産物等の再資源化 の率や質の向上を義務付けたり、推奨している。また、その際には、 ライフサイクルアセスメント(以下 LCA と略称)の結果が、評価・判 断の基準とすることに対する共通認識も定着している ${ }^{122334) ~}$ ような現状下にあって、全産業廃亜物の中で約 $20 \%$ を占める ${ }^{3)}$ 建設副 産物は、他産業に比べて適切かつ早急な対応が望まれている。

筆者らは、建設副産物の再資源化については 1974 年から、建築生 産における LCA については 1993 年から技術開発、評価システム等に

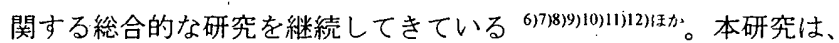
これら一連の研究に継続するものであり、建設副産物の再資源化を推
進する際の鍵を握っているとされている建設副産物の中間処理に焦 点を当てたうえで、これまで明かされていなかった中間処理の過程に お忛る二酸化炭素(以下 $\mathrm{CO}_{2}$ )排出量を定量的に推定したものである。 推定の手法としては、筆者らが、これまで、システム等の構筑に際し

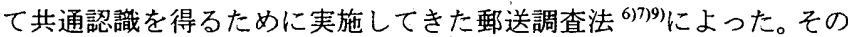
結果、中間処理段階における建設副産物の品目別の $\mathrm{CO}_{2}$ 排出量等が 高い精度で推定できた。本研究で推定した建設副産物の中間処理段階 における $\mathrm{CO}_{2}$ 排出量は、建築物のライフサイクルにおいて排出する $\mathrm{CO}_{2}\left(\mathrm{LCCO}_{2}\right)$ を、積上法 $\left.{ }^{4}\right)$ で予測する際の資料として使用できると考 える。

\section{2. 調査・研究概要}

\section{2-1。調查手法}

筆者らは、2001 年度日本建築学会大会(関東)において、木造住宅 5 棟の解体工事から運搬、中間処理に至る過程について、建設副産物発 生量、エネルギー消費量等を詳細に調查し、積上法 ${ }^{4} に よ よ る ~ \mathrm{CO}_{2}$ 排出

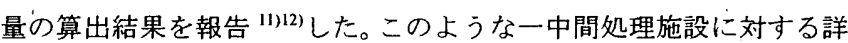
細な調查により得られた情報は、正確で、技術競合等による $\mathrm{CO}_{2}$ 排 出量の削減を期待できるものであるが、施設規模、処理品目・処理方 法、地域特性など各種条件が変化することで、調查結果を比較・検討、
* 明治大学理工学研究科建筑学専攻博士後期課程 工修

** 明治大学理工学部建築学科 教授. 工博

*** 明治大学理工学部建築学科 専任講師·工博

**** 明治大学理工学研究科建築学専攻博七前期課程
Graduate School of Science and Technology, Meiji Univ., M. Eng. Prof., Dept. of Architecture, Science and Technology, Meiji Univ., Dr. Eng. Assistant Prof., Dept. of Architecture, Science and Technology, Meiji Univ., Dr. Eng.

Graduate School of Science and Technology, Meiji Univ 
参考等に適用できない可能性がでてくる。そのため、中間処理施設の 調查母数を増やしていくことが求められる。そこで本研究は、調查母 数を増やすため、中間処理施設に訪問し建設副産物の処理量、エネル ギー消費量等を調查・測定する手法ではなく、郵送調查法によるアン ケート調査を行った。筆者らは、今までに、表 1 に示す郵送調查法に よるアンケート調查 ${ }^{677) 9}$ を実施している。その際、調查項目、設問が 妥当であり、1000 件以上の対象から 3 割程度の回答を回収すること が出来九ば、ほほ満足いく解析精度を確保出来ることを経験により得 ている。また、あらゆる条件の施設に対し調查を行うことで、調査結 果を比較・検討、参考等に用いる際の適用性は向上する。

表 1 筆者らが実施したアンケート調査

\begin{tabular}{|c|c|c|c|c|}
\hline $\begin{array}{c}\text { アンケート調查名称 } \\
\text { (調查期間) }\end{array}$ & $\begin{array}{c}\text { 有效 } \\
\text { 発送数 } \\
\text { (通) } \\
\end{array}$ & $\begin{array}{l}\text { 回収 } \\
\text { 数(通) }\end{array}$ & $\begin{array}{l}\text { 回収 } \\
\text { 率(\%) }\end{array}$ & 調査対象 \\
\hline $\begin{array}{l}\text { 解体、リサイクル、ダイオ } \\
\text { キシン、塩化ビニル建材 } \\
\text { ぞに関すアンーー調查 } \\
\text { (期間 : } 1999.2-1999.3 \text { ) }\end{array}$ & 1965 & 607 & 30.9 & $\begin{array}{l}\text { 産廃処理業者、解体業 } \\
\text { 者、住宅生産者、総合 } \\
\text { 建設、設業、諾務所。 } \\
\text { 建材商社、公害-環境 } \\
\text { 試験機関 }\end{array}$ \\
\hline $\begin{array}{l}\text { 建築業における外部コスト } \\
\text { 評価手法の道用可能性調查 } \\
\text { (期間 : 2000.2-2000.3) }\end{array}$ & 1023 & 271 & 26.5 & 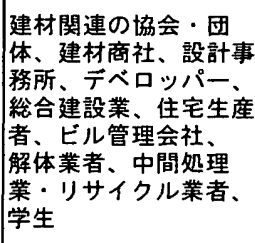 \\
\hline $\begin{array}{l}\text { 建築系混合磨㶳物中の廃プ } \\
\text { ラスチックク再資源化のため } \\
\text { の基礎調查 } \\
\text { (期間 : } 2000.10-2000.11 \text { ) }\end{array}$ & 1003 & 262 & 26.1 & \begin{tabular}{|l} 
中間処理業・最終処分 \\
業者、総合建設業、 \\
住宅生産者
\end{tabular} \\
\hline 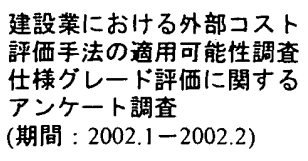 & 243 & 105 & 43.2 & 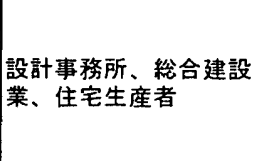 \\
\hline
\end{tabular}

アンケート調査実施に際し、筆者らが中心的な役割を果たしたものに限る

\section{2-2．調査対象及び調查結果の適用範囲}

調查対象は、全国における建設副産物を受け入れている(もしくは 受け入れることが可能な)中間処理施設を保有する団体・業者とし、

「2001 全国 産廃処分業 中間処理・最終処分 企業名覧・名鑑(以下 名覧・名鑑と略称)」 ${ }^{13}$ かから抽出を行った。そのため、本研究の調查 結果を比較・検討、参考等に適用できる範囲は、名覧・名鑑 ${ }^{13}$ に掲 載されている中間処理施設であり、2001 年以降新規参入もしくは増 設等の理由で掲載されていない中間処理施設に関しては、適用範囲外 である。

また、本研究における建設副産物の中間処理に伴う $\mathrm{CO}_{2}$ 排出量は、 中間処理施設の稼働により発生するものとする。そのため、木くずな どが含む有機物質の燃焼によって発生する $\mathrm{CO}_{2}$ については、カーボ ンニュートラルとして対象外とする。

\section{2-3. $\mathrm{CO}_{2}$ 排出原単位算出の対象及び調查項目}

本研究は、建設副産物の中間処理時における $\mathrm{CO}_{2}$ 排出量の算出を 簡易化するため、 $\mathrm{CO}_{2}$ 排出原単位の整備を行うものである。 $\mathrm{CO}_{2}$ 排出 原単位を算出する建設副産物を表 2 に示す。また、算出の対象とする 中間処理方法は、焼却、破砕、圧縮、減容、切断、選別とした。
表 2 二酸化炭素排出係数算出の対象とする建設副産物

\begin{tabular}{|c|c|c|}
\hline 建設副産物名称 & 意 味 & 記号 \\
\hline 木くず & 新築，改築，增築，除去等に伴う木くず & W \\
\hline がれき類 & 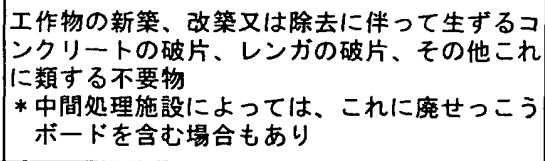 & Ru \\
\hline 糜プラスチック & 合成樹脂・合成穜維・発泡スチロールくず 等 & $\mathrm{PI}$ \\
\hline $\begin{array}{l}\text { 紙くず } \\
\end{array}$ & 新築、改築、增築、䟻去等に伴う紙くず & $\mathrm{Pa}$ \\
\hline 掝維くず & 新築、改築、增築、除去等に伴う樴維くず & $\mathrm{Fi}$ \\
\hline 廃ガラス & 新築、改築、增築、除去等に伴う廃ガうス & GI \\
\hline 廃せっこうボード & 新箖、ド改築、增築、賖去等に伴う麾せっこう & Gy \\
\hline 金属くず & 鉄くず，非鉄金属くず 等 & $\mathrm{Me}$ \\
\hline
\end{tabular}

$\mathrm{CO}_{2}$ 排出原単位 $\left(\mathrm{kg}-\mathrm{CO}_{2} / \mathrm{t}\right)$ は、 $\mathrm{CO}_{2}$ 排出量 $\left(\mathrm{kg}-\mathrm{CO}_{2}\right)$ と処理量 $(\mathrm{t})$ の除算 で求まる。そのため、調査項目は、この 2 つを算出するのに必要な項 目であり、以下のようになる。

\section{(1) 建設副産物の処理量}

- 対象団体・業者の保有する中間処理施設(以下対象施設と略称)の処 理能力

・対象施設が受け入れている産業廃棄物中、建設副産物の占める割合

・対象施設の保有する中間処理機器の稼働率

(2) $\mathrm{CO}_{2}$ 排出量

・対象施設における各エネルギー(電力、軽油、 $\mathrm{A}$ 重油、各種ガス等) の消費量

・各エネルギーの $\mathrm{CO}_{2}$ 排出倸数

上記調查項目の中で、処理能力に関しては、名覧・名鑑 ${ }^{13)}$ から、 $\mathrm{CO}_{2}$ 排出係数に関しては、”温室効果ガス排出量算定方法に関する検 討結果”'1)からデータベースとして整備を行った(整備結果を表 3、4 に示す)。また、これら調查項目は、アンケート調查の回収率を高め、

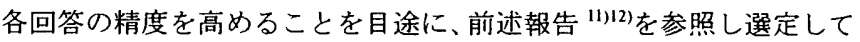
いる。

表 3 調査業者数及ひ処理能力合計 (千 $\mathrm{t} /$ 日)

\begin{tabular}{|c|c|c|c|c|c|c|c|c|}
\hline & & $\begin{array}{l}\text { 北海道 } \\
\text { 東 北 }\end{array}$ & 関 東 & $\begin{array}{l}\text { 甲信越 } \\
\text { 北 陸 } \\
\text { 東 海 }\end{array}$ & 近 幾 & $\begin{array}{ll}\text { 中 } & \text { 国 } \\
\text { 四 } & \text { 国 }\end{array}$ & $\begin{array}{ll}九 & \text { 州 } \\
\text { 沖 } & \text { 縄 }\end{array}$ & \\
\hline & 者数 & 214 & 174 & 263 & 152 & 135 & 127 & 1065 \\
\hline & $\mathrm{W}, \mathrm{Pa} \cdot \mathrm{Fi}$ 混合 & 5.70 & 3.39 & 7.94 & 3.87 & 1.94 & 0.43 & 23.27 \\
\hline 焼 & W & 4.77 & 0.14 & 0.33 & 0.29 & 0.10 & 0.16 & 5.78 \\
\hline 却 & $\mathrm{Pl}$ & 0.10 & 0.11 & 0.10 & 0.01 & 0.08 & 0.05 & 0.44 \\
\hline & $\mathrm{Pa} \cdot \mathrm{Fi}$ & 4.65 & 0.00 & 0.15 & 0.00 & 0.05 & 0.00 & 4.84 \\
\hline & Ru, Gl. Gy混合 & 16.86 & 19.63 & 20.76 & 19.64 & 10.84 & 8.01 & 95.73 \\
\hline & W & 7.39 & 3.32 & 3.15 & 0.95 & 2.34 & 1.58 & 18.73 \\
\hline & $\mathrm{Ru}$ & 49.28 & 36.31 & 61.41 & 35.62 & 32.38 & 33.08 & 248.08 \\
\hline 破 & Gl & 0.05 & 2.83 & 5.92 & 1.24 & 3.25 & 1.26 & 14.55 \\
\hline 砕 & $\mathrm{Pl}$ & 0.30 & 0.29 & 1.13 & 0.29 & 0.91 & 0.01 & 2.93 \\
\hline & $\mathrm{Fi}$ & 0.00 & 0.00 & 0.40 & 0.05 & 0.04 & 0.00 & 0.50 \\
\hline & Gy & 0.01 & 0.23 & 0.09 & 0.07 & 0.03 & 0.01 & 0.44 \\
\hline & $\mathrm{Me}$ & 2.68 & 0.60 & 1.22 & 0.32 & 2.97 & 0.08 & 7.86 \\
\hline 圧 & 縮 & 0.26 & 14.91 & 2.23 & 20.97 & 1.14 & 0.68 & 40.17 \\
\hline 晹 & 容 & 0.02 & 0.12 & 0.19 & 2.05 & 0.01 & 0.07 & 2.46 \\
\hline t] & ] 断 & 0.21 & 1.58 & 0.83 & 2.04 & 1.09 & 0.08 & 5.83 \\
\hline 選 & 別 & 4.01 & 1.38 & 5.44 & 13.13 & 1.10 & 9.65 & 34.71 \\
\hline 合 & 計 & 96.29 & 85.02 & 111.28 & 100.53 & 58.28 & 55.15 & 506.54 \\
\hline
\end{tabular}


表 4 各エネルギーの二酸化炭素排出係数

\begin{tabular}{|c|c|c|}
\hline エネルギー名称 & 二酸 & 排出係数 \\
\hline 天然ガス液（NGL） & 2.40 & $\mathrm{~kg}-\mathrm{CO}_{2} /{ }^{\prime \prime} \mathrm{k}$ \\
\hline ガソリン & 2.31 & $\mathrm{~kg}-\mathrm{CO}_{2} / \mathrm{H}_{\mathrm{n}} \mathrm{k}$ \\
\hline 灯 油 & 2.51 & $\mathrm{~kg}-\mathrm{CO}_{2} / \mathrm{k}^{\prime} \cdot \mathrm{r}$ \\
\hline 軽 油 & 2.64 & $\mathrm{~kg}-\mathrm{CO}_{2} / \mathrm{K}^{\prime \prime \prime}$ \\
\hline A重油 & 2.77 & $\mathrm{~kg}-\mathrm{CO}_{2} / \mathrm{k} \cdot \mathrm{m}$ \\
\hline 潤滑油 & 2.90 & $\mathrm{~kg}-\mathrm{CO}_{2} / \mathrm{K} / \mathrm{z}$ \\
\hline 液化石油ガス (LPG) & 3.02 & $\mathrm{~kg}-\mathrm{CO}_{2} / \mathrm{kg}$ \\
\hline 液化天然ガス（LNG) & $2.79^{\circ}$ & $\mathrm{kg}-\mathrm{CO}_{2} / \mathrm{kg}$ \\
\hline 天然ガス（LNGを除く） & 2.20 & $\mathrm{~kg}-\mathrm{CO}_{2} / \mathrm{m}^{3}$ \\
\hline 都市ガス & 2.15 & $\mathrm{~kg}-\mathrm{CO}_{2} / \mathrm{m}^{3}$ \\
\hline 一般電気事業者 & 0.357 & $\mathrm{~kg} \cdot \mathrm{CO}_{2} / \mathrm{kWh}$ \\
\hline その他電気供給者 & 0.602 & $\mathrm{~kg}-\mathrm{CO}_{2} / \mathrm{kWh}$ \\
\hline
\end{tabular}

\section{2-4. 各建設副産物中間処理の $\mathrm{CO}_{2}$ 排出原単位算出手順}

本研究による建設副産物中間処理の $\mathrm{CO}_{2}$ 排出原単位算出の流れを 図1に示す。

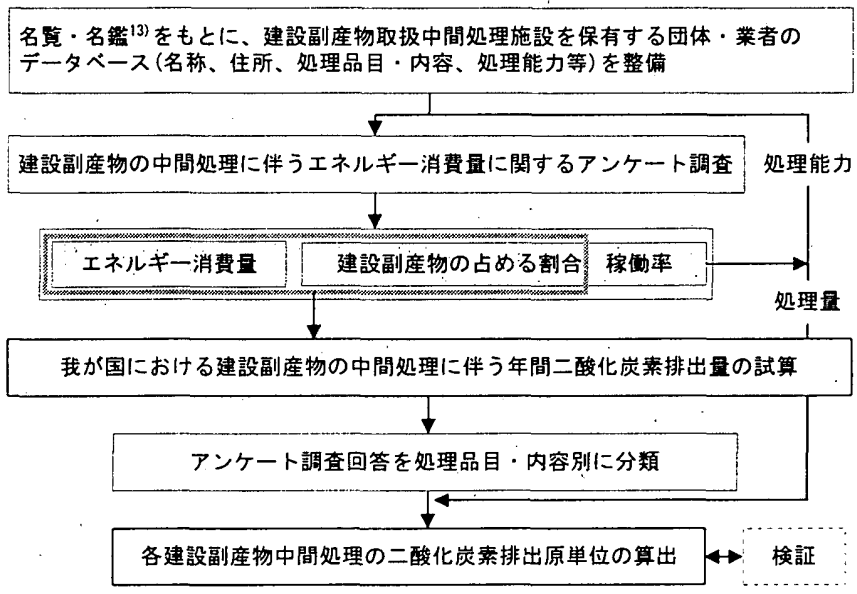

図 1 二酸化炭素排出原単位算出の流れ

本研究では、第一に、名覧・名鑑 ${ }^{13}$ によるデータベース並びにア ンケート調査結果を基に”我が国における建設副産物の中間処理に 伴う年間 $\mathrm{CO}_{2}$ 排出量”を算出している。従来、建築行為のライフサイ クルにおいて処理・処分時のエネルギー消費量は、他段階より比較 的少ないとされている ”。そのため、"我が国における建設副産物の 中間処理に伴う年間 $\mathrm{CO}_{2}$ 排出量”について試算した報告は少ない(2)15)。 そこで、本研究は、全国の中間処理施設を対象に行ったアンケート 調査結果から算出を行い、建築行為におけるライフサイクルアセス メントの基礎資料として整備を行った。

次に、アンケート調査回答について、名覧・名鑑 ${ }^{13} に$ にるデータ ベースを基に処理品目・処理方法別に分類・整理し、"各建設副産物 中間処理の $\mathrm{CO}_{2}$ 排出原単位”の算出を行った。また、詳細調查として 前述アンケート調查とは別に、各建設副産物の処理量及び各処理機 器のエネルギー消費量について調査を行い、算出した $\mathrm{CO}_{2}$ 排出原単 位の信頼性・妥当性について検証を行った。

またさらに、算出した $\mathrm{CO}_{2}$ 排出原単位を中心に、建設副産物の再 資源化率向上並びに中間処理時の環境負荷を抑制する方策について 考察を加えた。
3. 建設副産物の中間処理に伴うエネルギ一消費量に関するアンケー 卜調查

3-1. アンケート調查概要

アンケート調査は、本研究の根幹をなすデータを収集するために 行ったものであり、概要は以下のようになる。

(1) 目的

・各建設副産物中間処理の $\mathrm{CO}_{2}$ 排出原単位を算出するために必要 な情報を収集する。

- 再資源化率の向上並びに中間処理時の環境負荷低減の方策を検 討するための情報を収集する。

・筆者らが有する環境配虑の動向に関する情報を提供し、将来的 な環境負荷低減のための布石とする。

(2) 調查期間

・アンケート調査発送 : 2003 年 6 月.9. 日

・アンケート調查回答の回収期間 : 2003 年 6 月 10 日から 6 月末日

(3) 調查対象及び発送数

・アンケート調查対象は、名覧・名鑑 ${ }^{13}$ に掲載されている全国に おける建設副産物を受け入れている(もしくは受け入れ可能な)中 間処理施設を保有する団体・業者 1065 件とする(地域別発送数等は、 表 3 を参照)。

(4) 調查内容(全 4 問)

・設問 1 : 受け入れている産業廃棄物中、建設副産物が占める割合

・設問 2 : 対象施設の一ヶ月当たりのエネルギー消費量(月ごとの

変動を考慮した消費量の平均値)

・設問 3 : 対象施設の保有する中間処理機器の平均稼働率

・設問 4 : 建設副産物の受入品質基淮の設定状況(設定の有無、設 定している品目、設定内容)

(5) アンケート調查回答の回収

・アンケート調查回答は、設問・回答用紙に記入し、Faxにて回収 する。

・解析精度を確保するだけの回収数を得ることが出来た場合は、 未回答団体・業者に対して督促は実施せず、積極的に参加頂ける 団体・業者の回答を回収する。

\section{3-2. アンケート調査回収数及び回収率}

アンケート調査結果として、回収数・回収率を表 5 に、処理能力 別発送数及び回収数を図 2 に示す。

表 5 発送数及び回収数、回収率

\begin{tabular}{|c|c|c|c|c|c|}
\hline 発送地域区分 & $\begin{array}{c}\text { 棇発送数 } \\
\text { (通) }\end{array}$ & $\begin{array}{l}\text { 返送 } \\
\text { (通) }\end{array}$ & $\begin{array}{c}\text { 有効 } \\
\text { 発送数 } \\
\text { (通) }\end{array}$ & $\begin{array}{c}\text { 回収数 } \\
\text { (通) }\end{array}$ & $\begin{array}{c}\text { 回収乐 } \\
(\%)\end{array}$ \\
\hline 北海道·東北 & 214 & 0 & 214 & 60 & 28.0 \\
\hline 関東 & 174 & 2 & 172 & 59 & 34.3 \\
\hline 甲信越・北陸・東海 & 263 & 3 & 260 & 89 & 34.2 \\
\hline 近畿 & 152 & 3 & 149 & 31 & 20.8 \\
\hline 中国·四国 & .135 & 2 & 133 & 47 & 35.3 \\
\hline 九州・沖縄 & 127 & 2 & 125 & 37 & 29.6 \\
\hline 合 計 & 1065 & 12 & 1053 & 323 & 30.7 \\
\hline
\end{tabular}

アンケート調査の有効発送数は、転居先不明、2001 年以降に廃業 等の理由で返送された 12 通を引いた 1053 通となった。回収数の合計 は 323 通であり、有効発送数に対する回収率は $30.7 \%$ となった。本調 
查は、筆者らが過去に行った郵送調査法によるアンケート調査の経験 から、ほほ満足できる解析精度を確保出来る結果といえる。約 3 割の 回収率を得られたのは、調查対象が環境問題に高い関心を抱いていた こと、回収率並びに回答精度を高めるため設問設定に留意したことに よるものと考えられる。

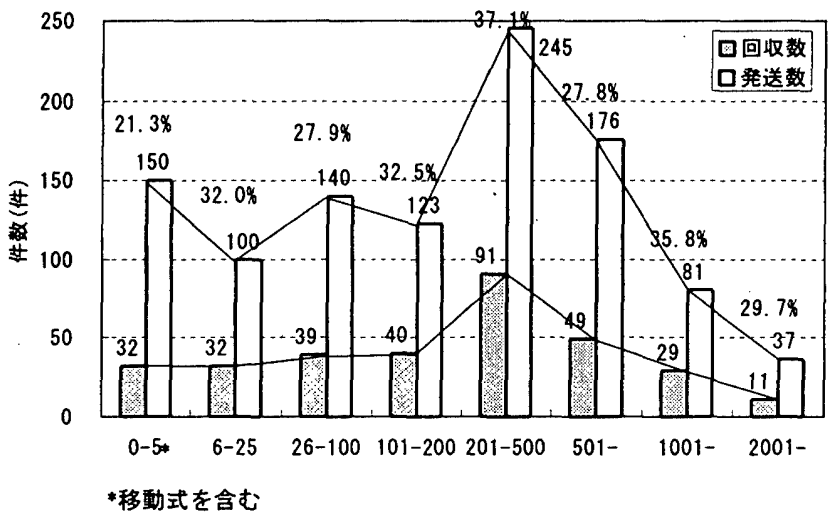

図 2 処理能力別発送数及び回収数

また、図 2 に示すように、アンケート調査回答の回収は、施設規模 の偏りがほとんどなく、様々な規模の施設からほほ均等に回答を得る ことが出来た。

\section{3-3. アンケート調查結果}

設問 1 から 3 の調查結果を表 6 に示す。設問 2 に関しては、対象施 設において使用している代表的なエネルギーとして、電力、軽油の年 間消費量について示す。

表 6 アンケート調查結果(設問 1、2、3)

\begin{tabular}{|c|c|c|c|c|}
\hline 発送地域区分 & $\begin{array}{c}\text { 電力 } \\
\text { 消費量 } \\
\text { (千kwh/年) }\end{array}$ & $\begin{array}{c}\text { 軽油 } \\
\text { 消費量 } \\
\left(k^{\prime} k^{\prime} / \text { 年) }\right.\end{array}$ & $\begin{array}{l}\text { 建設副産 } \\
\text { 物の占め } \\
\text { る割合 (\%) }\end{array}$ & $\begin{array}{c}\text { 稼働率 } \\
\quad(\%)\end{array}$ \\
\hline 北海道・東北 & 49269.7 & 3378.0 & 68.1 & 75.8 \\
\hline 関東 & 89719.3 & 8503.3 & 64.2 & 78.4 \\
\hline 甲信越·北陸 - 東海 & 40550.1 & 5820.1 & 76.6 & 71.0 \\
\hline 近裁 & 9758.8 & 2421.4 & 64.1 & 69.7 \\
\hline 中国·四国 & 37828.7 & 4044.7 & 65.9 & 71.8 \\
\hline 九州・沖縄 & 5705.0 & 2510.5 & 71.5 & 51.0 \\
\hline 合計 & 232831.6 & 26678.0 & 69.4 & 70.9 \\
\hline
\end{tabular}

設問 1 から 3 に関しては、九州・沖縄地域の平均䅝働率について他 地域と比べ若干低くなっていることを除けば、ほほ回収数(アンケー 卜調查回答施設の処理能力の合計)の差が結果に反映される結果とな った。

設問 4 の受入品質基準の設定状況に関する調查結果を表 7 に示す。

表 7 アンケート調查結果(設問 4)

\begin{tabular}{l|c|c|c|c|c|c|c|c}
\hline & $\mathrm{W}$ & $\mathrm{Ru}$ & $\mathrm{GI}$ & $\mathrm{PI}$ & $\mathrm{Pa}$ & $\mathrm{Fi}$ & $\mathrm{Gy}$ & $\mathrm{Me}$ \\
\hline $\begin{array}{l}\text { (アンケート調查回答施設中) } \\
\text { 各建設副産物受けれれ施設数 }\end{array}$ & 142 & 208 & 104 & 119 & 76 & 66 & 18 & 100 \\
\hline $\begin{array}{l}\text { 各建設副産物に対する } \\
\text { 受入品筫基準設定施設数 }\end{array}$ & 63 & 139 & 22 & 22 & 11 & 8 & 14 & 20 \\
\hline 受入品質基準設定率(\%) & 44.4 & 66.8 & 21.2 & 18.5 & 14.5 & 12.1 & 77.8 & 20.0 \\
\hline
\end{tabular}

廃せっこうボード、がれき類及び木くずは、アンケート調査回答施 設の中で受入品質基準設定率が高くなっている。がれき類は、特定建 設資材であるコンクリート塊が中心であることから、廃せっこうボー ドは、その中間処理によって、安定型又は管理型と処分方法が異なる ことから受入品質基準の設定率が高くなっていると考えられる。また、 木くずは、高い設定率を示しているが、その基準内容は、不純物の含 有に関するもの、破砕するための寸法・形状等に関するものが多く、 再資源化率向上には、更なる対応が必要と考えられる。

\section{4. 我が国における建設副産物の中間処理に伴う年間 $\mathrm{CO}_{2}$ 抹出量 4-1. 算出式}

建設副産物の中間処理に伴う年間 $\mathrm{CO}_{2}$ 排出量の算出式(a)を以下に 示す([ ]は単位)。

$A=\{[\Sigma(B \times C \times D) / 1000] /(E / F)\} \times 100 \cdots$ 算出式(a)

$\mathrm{A}$ : 我が国における建設副産物の中間処理に伴う年間 $\mathrm{CO}_{2}$ 排出量 $\left[\mathrm{t}-\mathrm{CO}_{2} /\right.$ 年 $]$

B：受け入れている産業廃棄物中、建設副産物が占める割合[\%]

$\mathrm{C}:$ 保有している全中間処理施設の年間エネルギー消費量 [kwh, 㜔, $\left.\mathrm{kg}, \mathrm{m}^{3}\right]$

$\mathrm{D}: \mathrm{CO}_{2}$ 排出俰数 ${ }^{(4)}\left[\mathrm{kg}-\mathrm{CO}_{2} / \mathrm{kwh},{ }_{\mathrm{r}}^{\prime \prime}, \mathrm{kg}, \mathrm{kg} \mathrm{m}^{3}\right]$

$\mathrm{E}:$ アンケート調查回答施設の処理能力合計 ${ }^{13}[\mathrm{t} /$ 年 $]$

F : 我が国における建設副産物受け入れ(もしくは受け入れ可能) 中間処理施設の処理能力合計[t/ 年]

$\mathrm{B} \times \mathrm{C} \times \mathrm{D}$ : 各中間処理施設における建設副産物の中間処理に伴 年間 $\mathrm{CO}_{2}$ 排出量 $\left[\mathrm{kg}-\mathrm{CO}_{2} /\right.$ 年 $]$

$\mathrm{E} / \mathrm{F}$ : 我が国における建設副産物受け入れ（もしくは受け入れ可 能)中間処理施設の処理能力合計中、アンケート調查回答施設 の処理能力が占める割合[\%]

算出式(a)は、アンケート調查回答施設の $\mathrm{CO}_{2}$ 排出量合計が、我が 国における建設副産物中間処理の中で占める割合について処理能力 を基に求め、その結果により全体量を算出するものである。そのため、 アンケート調査回答施設の規模の偏りは、算出に影響を及ぼすことに なるが、本調查では前述の通り特に支障はなかった。

対象の抽出に用いた名覧・名鑑 ${ }^{13}$ は、我が国における全ての中間 処理施設が掲载されているということを前提条件としている。そのた め、この算出は、未掲載の中間処理施設が存在する場合は、その分の $\mathrm{CO}_{2}$ 排出量を加える必要がある。しかし、建設業における建設副産物 の中間処理業の位置付けを知るための基礎資料としては、ほほ妥当な 精度といえる。

\section{4-2. 算出結果}

算出式(a)に基づく算出結果として、表 8 に、我が国における建設 副産物受け入れ(もしくは受け入れ可能)中間処理施設の処理能力合 計中アンケート調查回答施設の処理能力がしめる割合を示す。表 9 に、我が国における建設副産物の中間処理に伴う年間 $\mathrm{CO}_{2}$ 非出量を 示す。

算出の結果、本アンケート調查回答施設の処理能力合計は、我が国 全体の $32.3 \%$ であり、総発送数における回収率 $30.7 \%$ とほほ変わらな い值であった。これは、図 2 と同様に、施設規模の偏りなく回答の回 収を行えたことを立証している。 
表 8 建設副産物受入(もしくは受入可能)中間処理施設の処理能力 合計中、アンケート調查回答施設の処理能力が占める割合

\begin{tabular}{|c|c|c|c|c|}
\hline 発送地域区分 & $\begin{array}{c}F \\
\text { (t/日) }\end{array}$ & $\begin{array}{c}E \\
(\mathrm{~V} \text { 日) }\end{array}$ & $\begin{array}{l}F-E \\
(\mathrm{t} / \text { 日) }\end{array}$ & $\begin{array}{r}E / F \\
(\%)\end{array}$ \\
\hline 北海道 - 東北 & $95,206.8$ & $.31,809.0$ & $63,397.9$ & 33.4 \\
\hline 関東 & $87,784.3$ & $34,093.1$ & $53,691.2$ & 38.8 \\
\hline 甲俥越·北陸·東海 & $110,303.9$ & $41,978.9$ & $68,325.0$ & 38.1 \\
\hline 近畿 & $86,266.0$ & $15,191.2$ & $71,074.8$ & 17.6 \\
\hline 中国·四国 & $58,169.5$ & $19,721.8$ & $38,447.7$ & 33.9 \\
\hline 九州·沖縄 & $56,405.5$ & $16,700.6$ & $39,704.9$ & 29.6 \\
\hline 合 計 & $494,136.0$ & $159,494.6$ & $334,641.5$ & 32.3 \\
\hline
\end{tabular}

表 9 建設副産物の中間処理に伴う年間二酸化炭素排出量

\begin{tabular}{l|c|c|c}
\hline \multicolumn{1}{c|}{ 発送地域区分 } & $\begin{array}{c}\Sigma(\mathrm{B} \times \mathrm{C} \times \mathrm{D}) \\
\left(\mathrm{t}-\mathrm{CO}_{2} / \text { 年 }\right)\end{array}$ & $\begin{array}{c}\mathrm{E} / \mathrm{F} \\
(\%)\end{array}$ & $\begin{array}{c}\mathrm{A} \\
\left(\mathrm{t}-\mathrm{CO}_{2} / \text { 年 }\right)\end{array}$ \\
\hline 北海道·東北 & $13,779.8$ & 33.4 & $41,244.0$ \\
\hline 関東 & $43,228.8$ & 38.8 & $111,414.4$ \\
\hline 甲信越・北陸・東海 & $33,471.6$ & 38.1 & $87,852.0$ \\
\hline 近畿 & $4,287.9$ & 17.6 & $24,349.4$ \\
\hline 中国·四国 & $8,084.3$ & 33.9 & $23 ; 844.6$ \\
\hline 九州·沖縄 & $6,820.9$ & 29.6 & $23,043.6$ \\
\hline 合 計 & $109,673.2$ & 32.3 & $339,545.6$ \\
\hline
\end{tabular}

アンケート調査回答施設の建設副産物の中間処理に伴う年間 $\mathrm{CO}_{2}$ 排出量合計は、109,673.2(t-CO 2 )であり、ここまでの算出は実際のエネ ルギー消費量を基にしたものである。これが、全体の $32.3 \%$ 占める ものなので、我が国における建設副産物の中間処理に伴う年間 $\mathrm{CO}_{2}$ 排出量は、339,545.6(t- $\left.\mathrm{CO}_{2}\right)$ という算出結果を得ることが出来た。

この中間処理における $\mathrm{CO}_{2}$ 排出量は、建設行為のライフサイクル の中で施工時の年間排出量を約 $12,000\left(千 \mathrm{t}-\mathrm{CO}_{2}\right)^{(6)}$ とすると、これと 比較して $3 \%$ 程度となる。しかし、本研究では、木くずなどの焼却に よって発生する $\mathrm{CO}_{2}$ をカーボンニュートラルとして対象外としてお り、これを含めて考えるとこの数倍の $\mathrm{CO}_{2}$ が大気中に排出されてい ることになる。また、この中間処理時における. $\mathrm{CO}_{2}$ 排出量は、資源 循環に対する要求が高まる中で増加していくと予想され、他ライフサ イクル段階と比較して環境負荷低减に関する報告も少ないことから、 低減・抑制の余地も残っていると考えられる。

\section{5. 各建設副産物中間処理の $\mathrm{CO}_{2}$ 排出原単位}

\section{5-1. 算出概要}

各建設副産物中間処理の $\mathrm{CO}_{2}$ 排出原単位は、単位重量当たりの処 理に伴う $\mathrm{CO}_{2}$ 排出量であり、アンケート調査回答を処理品目・処理 方法別に分類・整理し、算出を行った。算出方法は、以下の 2 通りで ある。

\section{【算出方法(1)】}

一品目、一処理方法の施設(例えば、コンクリートの破砕のみを 行っている施設、木材の焼却のみを行っている施設等)の $\mathrm{CO}_{2}$ 排出 量を処理量で割ることで算出を行う(算出式(b))。

$$
\mathbf{G i}=\Sigma(\mathbf{H} \times \mathbf{B}) / \Sigma(\mathbf{I} \times \mathbf{B} \times \mathbf{J})
$$

$\mathrm{Gi}$ : 算出式(b)による建設副産物 $\mathrm{i}$ の単位重量当たりの中間処理に

伴う. $\mathrm{CO}_{2}$ 排出量 $\left(\mathrm{CO}_{2}\right.$ 排出原単位 $)\left[\mathrm{kg}-\mathrm{CO}_{2} / \mathrm{t}\right]$

$\mathrm{H}$ : 建設副産物 $\mathrm{i}$ のみを受け入れている中間処理施設の年間 $\mathrm{CO}_{2}$ 排出量 $\left[\mathrm{t}-\mathrm{CO}_{2} /\right.$ 年 $]$
I : 建設副産物 $\mathrm{i}$ のみを受け入れている中間処理施設の建設副産 物 $\mathrm{i}$ に対する処理能力 $[\mathrm{t} /$ 年 $]$

$\mathrm{J}$ : 建設副産物 $\mathrm{i}$ のみを受け入れている中間処理施設の稼働率[\%] B : 受け入れている産業廃棄物中、建設副産物が占める割合[\%] $\mathrm{I} \times \mathrm{B} \times \mathrm{J}$ : 建設副産物 $\mathrm{i}$ のみを受け入れている中間処理施設の建 設副産物 $\mathrm{i}$ の処理量[ $\mathrm{t} /$ 年]

\section{【算出方法(2)}

算出方法(2)は、複数品目、複数処理方法の施設から各建設副産物 の $\mathrm{CO}_{2}$ 排出原単位の算出を行う。

算出方法(1)は、 $\mathrm{CO}_{2}$ 排出量と処理量の関倸が明確である。しかし、 算出方法(1)による各 $\mathrm{CO}_{2}$ 排出原単位の算出は、ほぼ妥当な精度を 確保するために必要な算出に用いるアンケート調查回答(算出対象 施設)数の不足するものが大半である。そこで、算出方法(1による $\mathrm{CO}_{2}$ 排出原単位の算出において算出対象施設が多い $\mathrm{Ru}$ 一破砕、Ru， Gl，Gy 等混合一破砕、W一破砕の 3 つを用い、図 3 に示す手順に より算出方法(2)として各 $\mathrm{CO}_{2}$ 排出原単位の算出を行う。

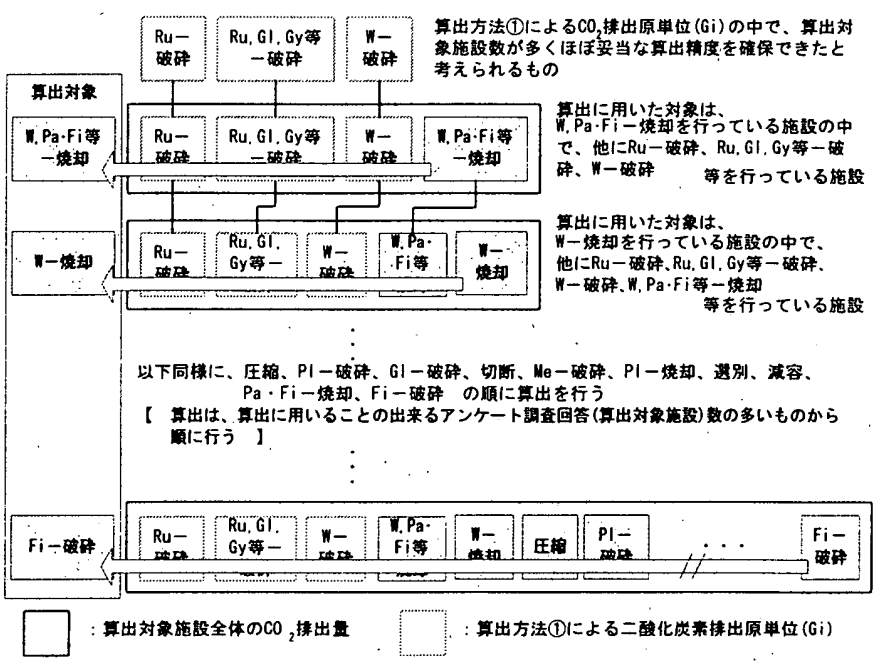

図 3 算出方法(2)による二酸化炭素津出原単位の算出手順

算出方法(2)による各 $\mathrm{CO}_{2}$ 排出原単位は、算出に用いるアンケート 調查回答(算出対象施設)全体の $\mathrm{CO}_{2}$ 排出量から、算出を行う建設副産 物の中間処理以外の $\mathrm{CO}_{2}$ 排出量を除くことで算出を行う。そのため、 算出方法(2による各 $\mathrm{CO}_{2}$ 排出原単位は、算出を行う建設副産物の中 間処理以外の $\mathrm{CO}_{2}$ 排出量を除く際に用いる $\mathrm{CO}_{2}$ 排出原単位の信頼性 がそしい場合は、その信頼性も低下寸る。そこで、算出方法(2)による $\mathrm{CO}_{2}$ 排出原単位の算出条件を以下のように設定した。

- 算出方法(1)による $\mathrm{CO}_{2}$ 排出原単位(Gi)の中で、算出方法(2)に用い るものは、算出に用いたアンケート調查回答(算出対象施設)数が 7 件以上の $\mathrm{Ru}$-破砕、 $\mathrm{Ru}, \mathrm{Gl}, \mathrm{Gy}$ 等混合一破砕、W一破砕の 3 つと する。

・算出方法(2)は、算出に用いることが出来るアンケート調查回答(算 出対象施設)数が多いものか.ら順に行う。

- 算出方法(2)、算出順を定めており、算出結果を順次用いて算出 を行う。しかし、算出に用いるのは、算出方法(2)による $\mathrm{CO}_{2}$ 排出 原単位(Gii)の中で、算出に用いたアンケート調査回答(算出対象施 設)数が 15 件以上のものとする。 
以上の条件により、算出方法(2)の算出精度に留意し、各建設副産物 中間処理に伴う $\mathrm{CO}_{2}$ 排出原単位の算出を行った。

\section{5-2. $\mathrm{CO}_{2}$ 排出原単位算出結果}

算出方法(1)、(2)による各建設副産物中間処理の $\mathrm{CO}_{2}$ 排出原単位の 算出結果を表 10 に示す。

表 10 各建設副産物中間処理の二酸化炭素排出原単位

\begin{tabular}{|c|c|c|c|c|c|}
\hline \multirow{2}{*}{\multicolumn{2}{|c|}{ 中間処理内容、品目 }} & \multicolumn{4}{|c|}{ 二酸化炭素排出原単位 $\left(\mathrm{kg}-\mathrm{CO}_{2} / \mathrm{t}\right)$} \\
\hline & & \multicolumn{2}{|c|}{ 算出方法(1) } & \multicolumn{2}{|c|}{ 算出方法(2) } \\
\hline \multirow{4}{*}{$\begin{array}{l}\text { 焼 } \\
\text { 却 }\end{array}$} & W，Pa·Fi等混合 & 71.87 & (4) & 112.07 & (66) \\
\hline & $\mathrm{w}$ & 117.92 & (2) & 112.33 & (33) \\
\hline & $\mathrm{Pa} \cdot \mathrm{Fi}$ & $*$ & $(0)$ & 2.36 & (2) \\
\hline & $\mathrm{Pl}$ & * & $(0)$ & 408.48 & (10) \\
\hline \multirow{8}{*}{ 破 } & Ru，Gl，Gy等混合 & 3.95 & $(27)$ & 3.73 & (90) \\
\hline & $\mathrm{Ru}$ & 3.49 & $(105)$ & 3.78 & (153) \\
\hline & $\mathrm{w}$ & 4.02 & $(8)$ & 3.76 & $(28)$ \\
\hline & $\mathrm{Gl}$ & 5.53 & (4) & 1.85 & (15) \\
\hline & $\mathrm{Pl}$ & 74.08 & (3) & 14.00 & (26) \\
\hline & Gy & 6.18 & $(1)$ & 8.31 & $(4)$ \\
\hline & $\mathrm{Me}$ & 34.84 & $(1)$ & 19.66 & (10) \\
\hline & $\mathrm{Fi}$ & $*$ & $(0)$ & 555.35 & $(2)$ \\
\hline \multicolumn{2}{|c|}{ 圧縮（対象：Ru，PI，GI，Me) } & 2.26 & (1) & 35.51 & $(28)$ \\
\hline \multirow{2}{*}{$\begin{array}{l}\text { 澸容 } \\
\text { 切断 }\end{array}$} & (対象: Ru, W $, \mathrm{PI}, \mathrm{Fi}$ ) & * & $(0)$ & 70.21 & $(5)$ \\
\hline & (対象 : PI, Me) & $*$ & $(0)$ & 3.37 & (11) \\
\hline 選別 & （対象：混合庭棄物） & $*$ & $(0)$ & 9.42 & $(10)$ \\
\hline
\end{tabular}

（）内の値は、算出に用いたアンケート調査回答(算出対象施設)数

各建設副産物中間処理の $\mathrm{CO}_{2}$ 排出原単位の算出結果より、木くず (W)に着目すると、木くず(W)の焼却は、破砕と比較して約 30 倍の二 酸化炭素を排出していることが分かる。これは、木くずを熱源として 利用することによる化石燃料の削減効果を配虑していないものであ るが、木くずを焼却する際は、その環境負荷の大きさから熱エネルギ 一の回収利用等の可能性を模索していく必要があるといえる。

\section{5-3．算出結果の検証}

建設副産物の中間処理に伴うエネルギー消費量に関するアンケー ト調査により算出した $\mathrm{CO}_{2}$ 排出原単位について、その信頼性・妥当 性を高めるため以下に示寸調查を行った。

(a) アンケート調查回答施設の一部に対する詳細調査

建設副産物の中間処理に伴う $\mathrm{CO}_{2}$ 排出量に関するアンケート調査 は、その回答率を高めるために、設問数を最小に抑え、その内容につ いて出来うる限り簡易化している。そのため、 $\mathrm{CO}_{2}$ 排出原単位の算出 に必要な各建設副産物の処理量について、データの一部を名覧·名鑑 13)を基に整備している。そこで、アンケート調査回答施設の中で、処 理品目を参考に抽出した 5 社に協力頂き、各建設副産物の処理量及び 各処理機器のエネルギー消費量について詳細な調查を行った。

(b) 中間処理機器メーカーに対する調査

建設副産物の中間処理に伴うエネルギー消費量に関するアンケー 卜調查とは別に、中間処理機器を製造するメーカーに対して、最大処 理能力とそれに伴うエネルギー消費量について調査を行った。調查対 象は、環境関連機材カタログ集 ${ }^{17)}$ を基に抽出し、15 社に協力頂いて いる。 (c) 既往の研究による $\mathrm{CO}_{2}$ 排出原単位の調査

既往の研究 ${ }^{3312) 18}$ (による $\mathrm{CO}_{2}$ 排出原単位の算出值を調查し、参照す る。

以上の検証調査から 2 通りの検証を行っている。

まず検証(その1)として、検証調査(a)より、各建設副産物の処理量 に $\mathrm{CO}_{2}$ 排出原単位を乗算し求める $\mathrm{CO}_{2}$ 排出予測量と、エネルギー消 費量に $\mathrm{CO}_{2}$ 排出係数を乗算し求める実 $\mathrm{CO}_{2}$ 排出量の比較を行った。 その結果を表 11 に示す。

表 11 検証調查結果(その 1$)$

\begin{tabular}{|c|c|c|c|c|c|}
\hline & A社 & B社 & C社 & D社 & E社 \\
\hline $\begin{array}{c}\mathrm{CO}_{2} \text { 抹出原単位に } \\
\text { よるる排出予測量 } \\
\left(\mathrm{kg}-\mathrm{CO}_{2}\right)\end{array}$ & 48567 & 107055 & 19716 & 18301 & 25941 \\
\hline $\begin{array}{c}\text { エネルギ一消費量 } \\
\text { より算出した俣 }{ }_{2} \\
\text { 排出量 }\left(\mathrm{kg}-\mathrm{CO}_{2}\right)\end{array}$ & 59710 & 102623 & 18564 & 18466 & 20144 \\
\hline 合致率 & 81.3 & 104.3 & 106.2 & 99.1 & 128.8 \\
\hline \multirow{9}{*}{ 受入品目・内容 } & $\mathrm{W}, \mathrm{Pa} \cdot \mathrm{Fi}$ 等 & Ru,Gl,Gy等 & $\mathrm{Ru}$ －破碎 & W-焼却 & $\mathrm{W}, \mathrm{Pa} \cdot \mathrm{Fi}$ 等 \\
\hline & 混合-焼却 & 混合-破研 & W一破䂶 & Ru,Gl;Gy等 & 混合-焼却 \\
\hline & Ru,Gl,Gy等 & Ru一破碎 & PI一破碚 & 混合-破碎 & $\mathrm{Ru}, \mathrm{Gl}, \mathrm{Gy}$ 等 \\
\hline & 混合-破碎 & W-破䂶 & Gy一破研 & $\mathrm{Ru}$-破碎 & 混合-破碎 \\
\hline & $\mathrm{Ru}$-破碎 & $\mathrm{PI}$ 一破碚 & $\mathrm{Me}$ 一破碎 & W-破碚 & Gy一破碎 \\
\hline & W一破碎 & $\mathrm{Me}$-破碚 & 選別 & & PI一破碎 \\
\hline & PI-破碎 & 圧縮 & \multirow{3}{*}{-} & & 減容 \\
\hline & \begin{tabular}{|l}
$\mathrm{Me}$ 一破研 \\
\end{tabular} & 選別 & & & 圧縮 \\
\hline & 圧縮、選別 & - & & & 選別 \\
\hline
\end{tabular}

合致率は、(排出予測量 $/$ 実排出量) $\times 100$ で求める

合致率は、若干のばらつきが見られるものの、概ね問題ない範囲を 得ることが出来た。これにより、本研究における $\mathrm{CO}_{2}$ 排出原単位の 算出方法、手順等は妥当であったといえる。

次に、検証(その 2)として、検証調查(a)、(b)、(c)より、本研究にお ける $\mathrm{CO}_{2}$ 排出原単位の算出方法とは別の手法を用いて $\mathrm{CO}_{2}$ 排出原単 位を算出し、検証を行った。その結果を表 12 に示す。

表 12 検証調査結果(その 2)

\begin{tabular}{|c|c|c|c|c|c|c|}
\hline \multirow{3}{*}{\multicolumn{2}{|c|}{ 中間処理内容、品目 }} & \multirow{3}{*}{$\begin{array}{c}\text { 二酸化炭素 } \\
\text { 排出原単位 } \\
\left(\mathrm{kg}-\mathrm{CO}_{2} / \mathrm{t}\right)\end{array}$} & \multirow{3}{*}{\begin{tabular}{|l} 
算出 \\
方法
\end{tabular}} & \multicolumn{3}{|c|}{ 検証調査 } \\
\hline & & & & (a). & & (c) \\
\hline & & & & \multicolumn{3}{|c|}{$\left(\mathrm{kg}-\mathrm{CO}_{2} / \mathrm{t}\right)$} \\
\hline \multirow{4}{*}{$\begin{array}{l}\text { 焼 } \\
\text { 却 }\end{array}$} & $\mathrm{W}, \mathrm{Pa} \cdot \mathrm{Fi}$ 等混合 & $112.07(66)$ & (2) & - & - & $400.48^{12)}$ \\
\hline & W & $112.33(33)$ & (2) & 199.07(b) & - & - \\
\hline & $\mathrm{Pa} \cdot \mathrm{Fi}$ & $2.36 \quad(2)$ & (2) & - & - & - \\
\hline & $\mathrm{Pl}$ & $408.48(10)$ & (2) & $537.33(\mathrm{~b})$ & $504.75(\mathrm{~b})$ & - \\
\hline \multirow{8}{*}{$\begin{array}{l}\text { 破 } \\
\text { 碎 }\end{array}$} & Ru,Gl,Gy等混合 & $\begin{array}{|ll|}3.95 & (27) \\
\end{array}$ & (1) & - & - & - \\
\hline & $\mathrm{Ru}$ & $3.49(105)$ & (1) & - & - & $4.5^{18)}$ \\
\hline & W & $\begin{array}{|ll|}4.02 & (8) \\
\end{array}$ & (1) & 4.41 (a) & 4.28 (b) & - \\
\hline & $\mathrm{Gl}$ & $1.85 \quad(15)$ & (2) & - & - & - \\
\hline & $\mathrm{Pl}$ & $14.00(26)$ & (2) & $10.71(b)$ & $26.18(b)$ & - \\
\hline & Gy & $8.31 \quad(4)$ & (2) & $8.51(\mathrm{~b})$ & - & - \\
\hline & $\mathrm{Me}$ & $19.66(10)$ & (2) & $13.20(a)$ & - & - \\
\hline & $\mathrm{Fi}$ & $555.35(2)$ & (2) & - & - & - \\
\hline 圧 & 縮 & $35.51(28)$ & (2) & $28.11(\mathrm{~b})$ & - & - \\
\hline 洞 & 容 & $70.21 \quad(5)$ & (2) & $39.27(\mathrm{~b})$ & - & - \\
\hline t) & 断 & $3.37(11)$ & (2) & - & - & - \\
\hline \multirow{2}{*}{\multicolumn{2}{|c|}{ 選 別 }} & \multirow[t]{2}{*}{$9.42 \quad(10)$} & \multirow[t]{2}{*}{ (2) } & \multirow[t]{2}{*}{34.32 (a) } & \multirow[t]{2}{*}{$0.31(b)$} & $6.1^{31}$ \\
\hline & & & & & & $11.99^{12)}$ \\
\hline
\end{tabular}

$\mathrm{CO}_{2}$ 排出原単位の後にある( )内の值は、算出に用いたアンケート調査回答数 
本研究において算出した $\mathrm{CO}_{2}$. 排出原単位の中で、算出方法(1)の算 出に用いたアンケート調查回答(算出対象施設)数が多い、 $\mathrm{Ru}$ 一破砕、 W一破砕は、検証調查(a)、(b)および(c)の結果より信頼性・妥当性の 高い值といえる。

算出方法(2)による $\mathrm{CO}_{2}$ 排出原単位に関しても、木くず(W)関連の焼 却以外で、対象件数が 10 件を超えるものは、信頼性・妥当性の高い 算出が出来たといえる。木くず(W)関連の焼却に関しては、建設副産 物の中間処理に伴うエネルギー消費量に関するアンケート調查の結 果においても、施設によるエネルギー消費量の差が大きく、検証調査 の事例を増やしていく必要がある。また、算出に用いた対象件数が少 ないものに関しては、現段階で算出値の信頼性を確保出来たとはいえ ず、今後、更なる調查が必要といえる。

\section{5-4. $\mathrm{CO}_{2}$ 排出原単位による中間処理施設の評価モデル}

本研究により算出した $\mathrm{CO}_{2}$ 排出原単位は、全国の中間処理施設に 対し調査を行い大小様々な規模の施設からほぼ均等に回答を得てい ることから、我が国における建設副産物中間処理の平均的な值といえ る。そこで、この $\mathrm{CO}_{2}$ 排出原単位を、我が国における各建設副産物 の平均的な再資源化率をなす時の $\mathrm{CO}_{2}$ 排出原単位と仮定し、表 13 に 示す評価モデルを設定した。

\section{表 13 中間処理施設の評価モデル}

\begin{tabular}{|c|c|c|c|}
\hline モデル & $\begin{array}{l}\text { 環境 } \\
\text { 負荷 }\end{array}$ & \begin{tabular}{|l|l} 
再資 \\
化
\end{tabular} & $\begin{array}{l}\text { 持続的発展可能な経済社会 } \\
\text { に向けて取り組むべき刘策 }\end{array}$ \\
\hline $\begin{array}{l}\mathrm{I} \mathrm{CO}_{2} \text { 排出量が標準値 } \\
\text { 再資源化率が標準値 }\end{array}$ & $\Delta$ & $\Delta$ & $\begin{array}{l}\text { エネルギー効率向上 } \\
\text { 再資源化率向上 }\end{array}$ \\
\hline 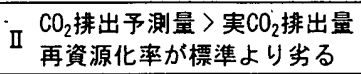 & 0 & $x$ & 再資源化率大幅向上 \\
\hline 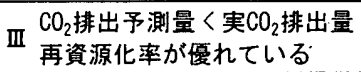 & $x$ & 0 & エネルギー効率の大幅向上 \\
\hline $\begin{array}{l}\mathrm{IV} \mathrm{CO}_{2} \text { 排出予測量く実 } \mathrm{CO}_{2} \text { 排出量 } \\
\text { 再資源化率が標準より劣る }\end{array}$ & $x$ & $x$ & $\begin{array}{l}\text { エネルギー効幽大幅向上 } \\
\text { 再資源化率大幅向上 }\end{array}$ \\
\hline
\end{tabular}

$O$ : 標準より優れている $\Delta$ : 標準値 $\times$ : 標準より劣る

この評価モデルにおいて環境負荷は、表 11 に示すように、 $\mathrm{CO}_{2}$ 排 出予測量と実 $\mathrm{CO}_{2}$ 排出量を比較し評価する。再資源化は、我が国に おける各建設副産物の再資源化率と各中間処理施設により中間処理 された建設副産物の再資源化施設への搬入率を比較し評価する。

ここでは、評価モデルをIからIVの 4 種類設定しており、各モデル における今後、『持続的発展が可能な経済社会の構策』のために取り 組むべき対策を示した。

以上のように本研究で算出した $\mathrm{CO}_{2}$ 排出原単位を活用することで、 各中間処理施設の課題(もしくは優れている点)が明確になる。これに より、エネルギー効率の優れた中間処理または、再資源化率向上に資 する中間処理として、技術競合が期待出来るため、環境負荷の抑制・ 低減につながると考えられる。

\section{6. おわりに}

本研究では、全国における建設副産物受け入れ（もしくは受け入れ 可能)中間処理施設を保有する団体・業者に対して、エネルギー消費 量など $\mathrm{CO}_{2}$ 排出量算出に必要な情報を収集するため郵送調查法によ るアンケート調査を行った。得られた結果を以下に示す。

(1) 建設副産物の中間処理に伴う $\mathrm{CO}_{2}$ 排出量に関するアンケート調
查では、有効発送数 1053 通に対し、回収数 323 通、回収率 $30.7 \%$ であった。これは、ほほ満足出来る精度で解析を行える回収数、回 収率といえる。また、この回収率により、中間処理業に携わる方々 にとってこの種の問題に対する関心・認識が高いことがうかがえる。 (2) 我が国における建設副産物の中間処理に伴う年間 $\mathrm{CO}_{2}$ 排出量の 算出を行ったところ、約 34 万 $\mathrm{t}-\mathrm{CO}_{2} /$ 年ということが分かった。こ れは、建設行為のライフサイクルの中で施工時と比較すると、約 3\%程度である。

（3）各建設副産物中間処理の $\mathrm{CO}_{2}$ 排出原単位の算出を 2 通りの方法 で行った。その検証を行ったところ、算出方法(1)では、算出に用い た対象施設数が 7 件以上、算出方法(2)では、木くず(W)関連の焼却 を除き、対象施設数が 10 件以上において、精度の高い算出を行え ていることが分かった。木くず(W)関連の焼却に関しては、今後、 詳細調查による検証事例を増やしていく。

(4)、本研究により算出した $\mathrm{CO}_{2}$ 排出原単位の活用方法として、建設 副産物の再資源化率を合わせた中間処理施設の評価モデルの設定 を行った。また、各モデルに対し、『持続的発展が可能な経済社会 の構築』のために取り組むべき対策を示した。

(5) 本研究は、建築物の $\mathrm{LCCO}_{2}$ を積上法で予測する際の基礎資料と して使用するものである。筆者らは他に、撤去・解体から最終処理・ 処分されるまでの一連の行為に対する一元化システムの構築を進 めており、中間処理と他段階を結ぶための布石として、受入品質基 準の設定状況等の調查も行っている。今後、一元化システム構築の ため、更なる検討を行っていく。

\section{参考文献}

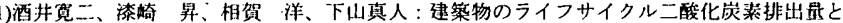
その抑制方法に関寸る研究、日本建築学会㖕画系論文集、Vol.484、p.p.105 112、1996.6 2)伊香賀俊治、村上為三、加藤信介、白砥端幸 : 我が国の建築関連 $\mathrm{CO}_{2}$ 排出量の 2050 年ま での予测、建築・都市の㻴境負荷評伍に関する研究、日本建築学会計画系論文集、Vol.535、 p.p. $53 \sim 58,2000.9$

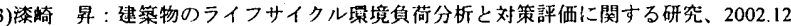

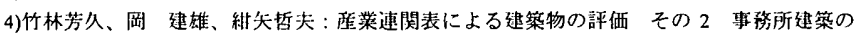

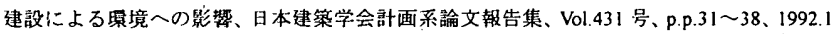

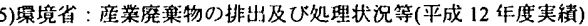

6)建築業における外部コスト評価手注の適用可能性の調查委員会：建築分野における圂境

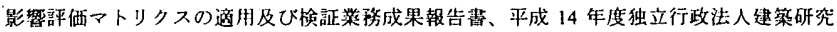
所委䚾、(剘)建材訳験センター: 2003.3

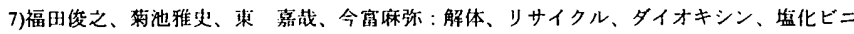
ル建材などに関する動问 その、解体・リサイクル全般に関する調査秥果及び解析、

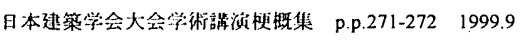

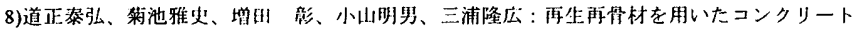
の棈造用コンクリートへの適用 原モルタルの性質が再生再骨材および再生コンクリー

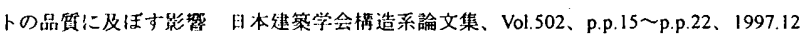

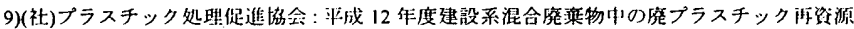

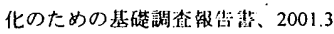

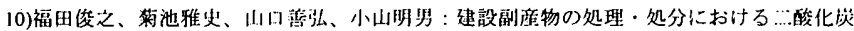

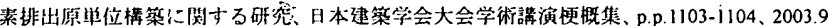
11)福田俊之、金村千絵、大㿟正明、村上泰司、篓池雅史：解体段階におけるエネルキー健

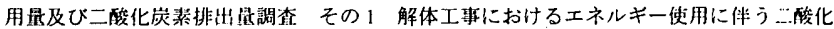

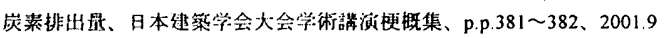

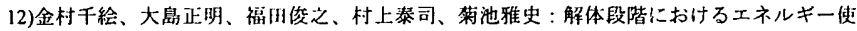

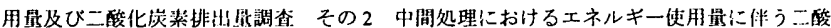

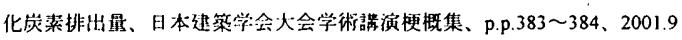

13)(怢)日報了イ・ビ一編：2001 全国 産廃処分業 中開処理・最終処分 企業 名筧・名爁、

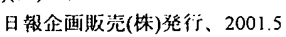

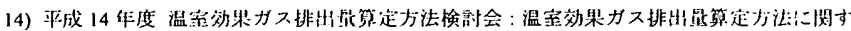

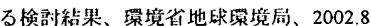

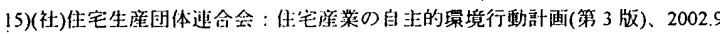

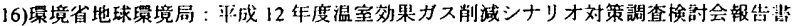

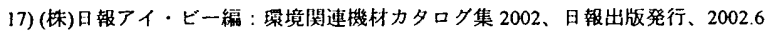

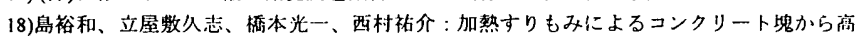
品質骨材回収の LCA 評侕、コンクリート工学年次論文集、Vol.23、No.2、p.p.67-72、2001 